\title{
Settlement Analysis of Geosynthetics Reinforced Embankments
}

\author{
Mohammad Salem NOORI ${ }^{1, *}$, Kaveh DEHGHANIAN ${ }^{2}$ \\ ${ }^{1}$ Istanbul Aydin University, Civil Engineering Department, salem.noori06@ gmail.com, Orcid No: 0000-0003-1729-4415 \\ ${ }^{2}$ Istanbul Aydin University, Civil Engineering Department, kavehdehghanian@aydin.edu.tr, Orcid No: 0000-0002-6372-4984
}

\begin{tabular}{ll}
\hline ARTICLE INFO & ABSTRACT \\
\cline { 2 - 2 } Article history: & $\begin{array}{l}\text { Geosynthetics have been used in many construction and environmental projects in recent years, and the } \\
\text { use of geosynthetic products as an effective element is increasing. These materials, as reinforcement, can } \\
\text { solve the problems of building heavy structures and roads on weak soils without the need for excavation } \\
\text { or filling, foundation, and sub-foundation operations. In this study, using different number and type of } \\
\text { Received in revised form } 7 \text { July } 2021\end{array}$ \\
$\begin{array}{l}\text { Accepted } 7 \text { July } 2021 \\
\text { Available online } 28 \text { September } 2021\end{array}$ & $\begin{array}{l}\text { soil layers are investigated. The road superstructures consist of three layers. Different geosynthetic are } \\
\text { modeled with the finite element program, PLAXIS, to examine the modeling results. By application of }\end{array}$ \\
\hline Keywords: & $\begin{array}{l}\text { Geogrids as different layers of the road, the amount of settlement decreases significantly. It can be seen } \\
\text { that the most reduction occurs in application of three geogrids in soil profile though the total displacement } \\
\text { decreases by increasing the number of geogrids. On theother hand, it can be concluded that application of } \\
\text { geotextiles does not affect the settlement regardless of the layer numbers. Moreover, it can be concluded } \\
\text { Settlement, Embankment } \\
\text { that the order of soil layers does not have any significant effect on the settlement rate. }\end{array}$
\end{tabular}

Doi: 10.24012/dumf.1002256

* Sorumlu Yazar

\section{Introduction}

Due to critical problems of soft soils such as low bearing capacity and high settlement, there are different methods of strengthening the soils for soft soils which include mechanical and chemical improvement of soils. These methods generally increase the resistance and load-carrying capacity. This reduces the potential for soil swelling and shrinkage. On the other hand, natural fibers have been used for a long time to overcome the weakness of soils against tensile stress, and today, with the development of various sciences, polymeric materials such as geosynthetics are used. Geogrid and geotextile lead to an increase in their use in ground structures, increase in bearing capacity, and decrease in the volume of ground treatments, rapid application, and compatibility with the natural environment [1]. By increase in the tensile strength of the geotextile reinforcement, the safety factor increases [2]. Since displacement does not have a significant effect on increasing the tensile strength of the geotextile, this parameter has been neglected in determining the optimum tensile strength of the geotextile [3]. Several authors have investigated the effect of geosynthetics on soil layers. Using the case of two layers of geogrids, Bayram concluded that the amount of settlement in the thinner section was reduced by $4.01 \mathrm{~mm}$. Although the filling thickness was decreased by $42.5 \mathrm{~cm}$, it was observed that the amount of settlement decreased [4]. In another study, use of pavement geogrids of flexible roads and the output results with the PLAXIS 2D program showed the beneficial effects of the axial stiffness of the geogrids in the base layer and the interfacial strength of materials of different thicknesses on the vertical surface deformation. Vertical surface deformation did not decrease much when using a geogrid [5]. Studies on the slope reinforced with geosynthetic material depicted that reinforced slope is safer and gave better settlement and shear stress results [6]. The desired improvement has not been achieved in the single geosynthetic reinforced state under the foundation. A relatively more load-sitting behavior was exhibited in models with multiple reinforcements ( $\mathrm{N}=2$ and 3) [7]. Unlike the properties of geotextiles, environmental factors (the environmental pressure at which the experiments are conducted) can affect test results, especially at normal pressures, the effect of other factors is reduced [8]. Later on, it was shown that Geogrid increases the stability of the road and extends the life of the road and offers economical solutions in terms of cost. On the other hand, the decrease in the filling thickness shortens the construction period [9]. It was shown that undrained shear strength increases when geotextiles are used [10]. Moreover, Geosynthetics prevent the separation of soil layers and provide soil drainage. It provides long and short-term stability in the use of geosynthetics in fill foundations, limits different settlements, and can prevent 
slumping [11]. It was also proven that Geogrids, first of all, provide the compression of the foundation layers and then they increase the strength [12]. The use of geogrids applied in the upgrading process has provided economical, fast, stable and useful, and functional solutions [13].

In the above mentioned studies, limited number of layers were investigated. Moreover the effect of soil types and the impact of layer orders in settlement has not been investigated carefully. Furthermore, the impact of the number of the geosynthetic layers on the settlement of soft soils is missing. This study aims to highlight these shortcomings.

\section{Materials and method}

\section{Material models}

In this study, different soil profiles and geosynthetic materials have been studied. With a generally uniform cross-section, loading scheme, and a large extent in the $\mathrm{z}$ direction, the plane strain model is suitable for implementation. Normal stresses are fully considered in the z-direction, but displacements and strains are assumed to be zero. A 15-node mesh is consiedered in this study. The difference between soil profiles depends on how accurately the soil has to be stressed in its mechanical behavior. The design for each model defines the relationship between stress and strain in the material. In the models, different layers with two different soil types are used as asphalt, foundation, sub-base , and ground sub-base. Using different geosynthetic materials as shown in Figure 1, the settlements of this different soil are compared. A total of 14 models were formed on these two soils and analyzed with the PLAXIS program. The road width is 7.30 and a two lane road with a shoulder width of $1 \mathrm{~m}$ for each lane has been chosen $[14,15]$. Pavement slope (2-3\%) and shoulder slope $(2-3 \%)$ are selected [15]. These models were named as model A1 (with no geosynthetics, two clay liners and one sand), model B1 (no geosynthetics used, sand layer under the foundation), model A2 (single layer geogrid in the middle of asphalt), model B2 (single layer geogrid in the middle of asphalt), model A3 (middle of asphalt, sand and two layers of geogrid used between subbase), model B3 (middle of asphalt, two layers of geogrid between sand and subbase), model A4 (middle of foundation, two layers of geotextile between foundation and subbase), model B4 (middle of foundation, foundation and two layers of geotextiles are used between the sub-base), model A5 (single layer geogrid is used in the middle of the foundation), model B5 (single layer geogrid is used in the middle of the foundation), A6 (mid-asphalt, between asphalt and foundation, between foundation and sub-base, sub-base and Geogrid was used in four layers between clay), B6 (mid-asphalt, between asphalt and foundation, between foundation and sub-base, between subbase and sand), A7 (asphalt and foundation, a Geogrid and geotextile are used in two layers between the foundation and clay in two layers, the middle of the foundation, the two layers between the foundation and the subbase), B7 (between the asphalt and the foundation, the subbase and the sand, two layers of geogrid and the middle of the foundation, two layers of geotextile between the foundation and the subbase are used).

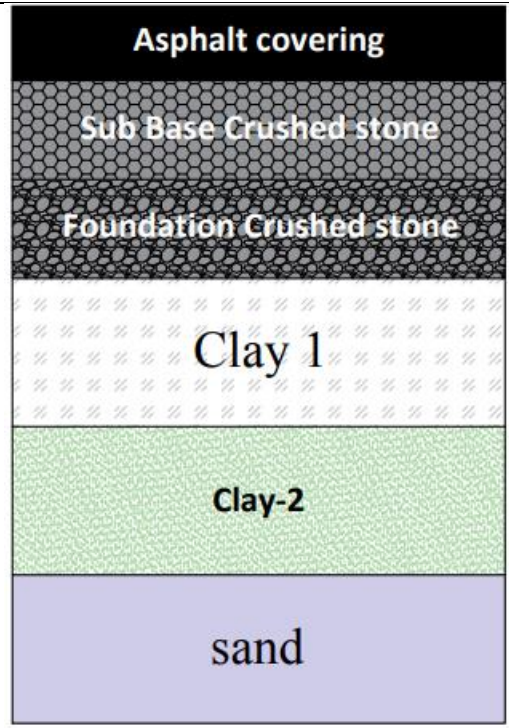

MODEL A1

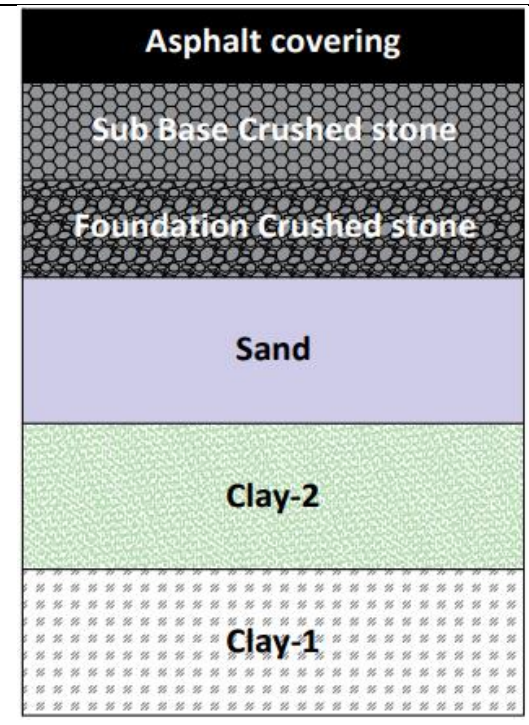

MODEL B1 


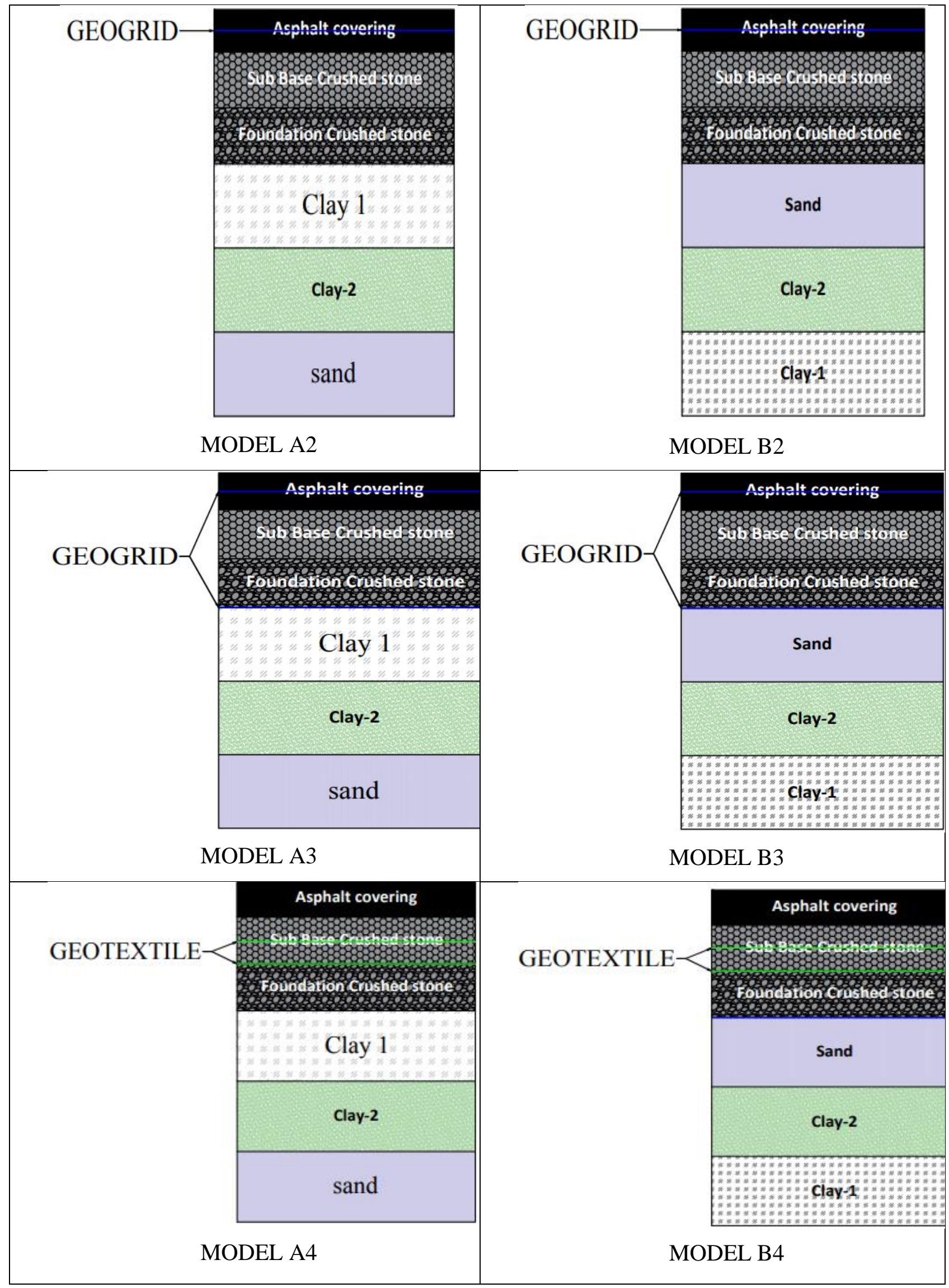




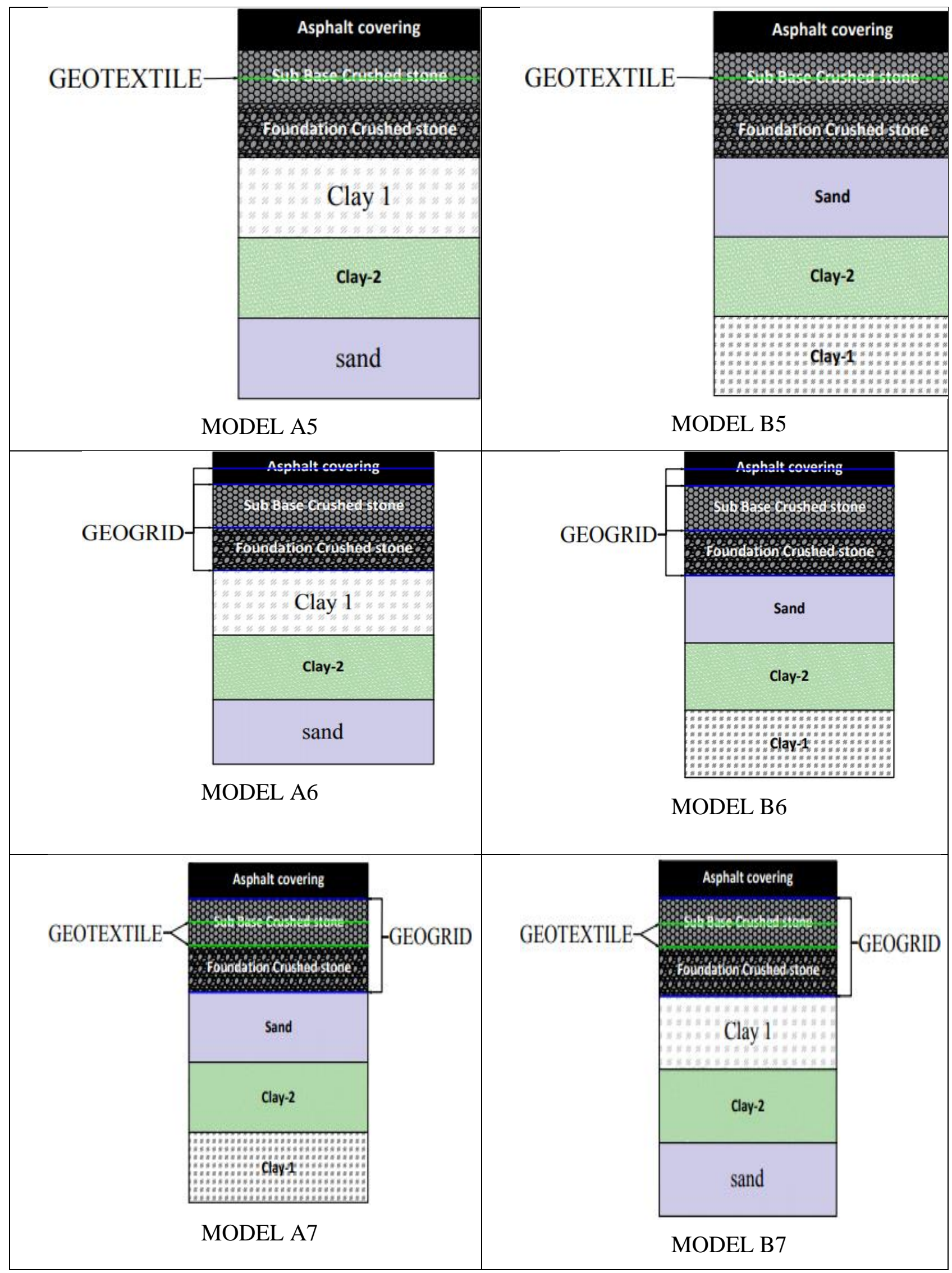

Figure 1. Cross section of two types of soil (A, B) 


\section{(Linear isotropic elasticity) model}

The Liner Elastic soil model is the simplest stress-strain relationship found in PLAXIS. This model has only two input parameters, Young's modulus, E, and Poisson ratio, $v$. Such a model is not suitable for explaining the complex behavior of the soil but is suitable for modeling larger structural members and bedrock layers.

\section{Mohr-Coulomb model}

Mohr-Coulomb is an elastic-plastic model containing five input parameters, $\mathrm{E}$ and $v$ for soil elastic, $\varphi$ and $\mathrm{c}$ for soil plasticity, and angle. It is recommended to use MohrCoulomb for the evaluation of initial deformations. This is because other advanced models need more ground data than
Mohr-Coulomb. Mohr-Coulomb model has been well able to model soil behavior [16] and the full plastic floor behavior is done with this model.

\section{Features of Geosynthetics}

Geogrids are thin structures that have normal stiffness but no bending stiffness. Geogrids can only handle tensile forces and do not compress. These objects are often used to model ground reinforcements. Geogrids are modeled using "geogrid" elements that have only one (axial) degree of freedom at each node and cannot handle compression forces. The material and geometric properties used in modeling the geogrid are given in Table 1 .

Table 1. Geogrid and geotextile properties

\begin{tabular}{|l|l|l|l|c|}
\hline Parameter Name & Symbol & Unit & Value & Reference \\
\hline Geogrid & EA & $\mathrm{kN} / \mathrm{m}$ & $1 \times 10^{5}$ & {$[17]$} \\
\hline Geotextile & EA & $\mathrm{kN} / \mathrm{m}$ & $10 \times 10^{5}$ & {$[5]$} \\
\hline
\end{tabular}

\section{Geogrid and Geotextile Layout and Functions in Road Coverings}

Geogrid and geotextile are used from geosynthetic materials. These materials are as shown in figure 2 for road pavements [24].

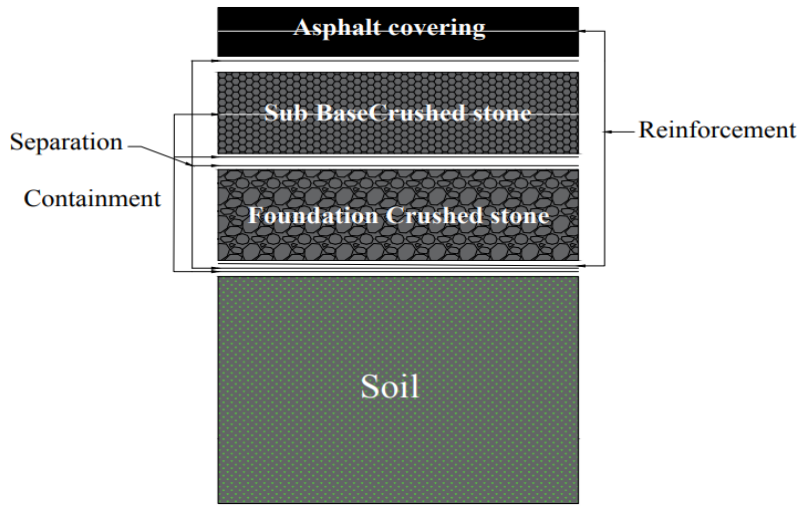

Figure 2. The purpose of the distribution of geosynthetic materials on the road [24]

These are on different soils, different layers of soils with different numbers of different materials were used in Figure 2 and examined with the PLAXIS program.

\section{Loading Areas and Quantity}

In the loading section, a vehicle weighing $29000 \mathrm{~kg}$ has been selected which corresponds to 6 tire loads. In this study, each tire transfers a load of $246.2 \mathrm{kN} / \mathrm{m}^{2}$ to the ground [18].

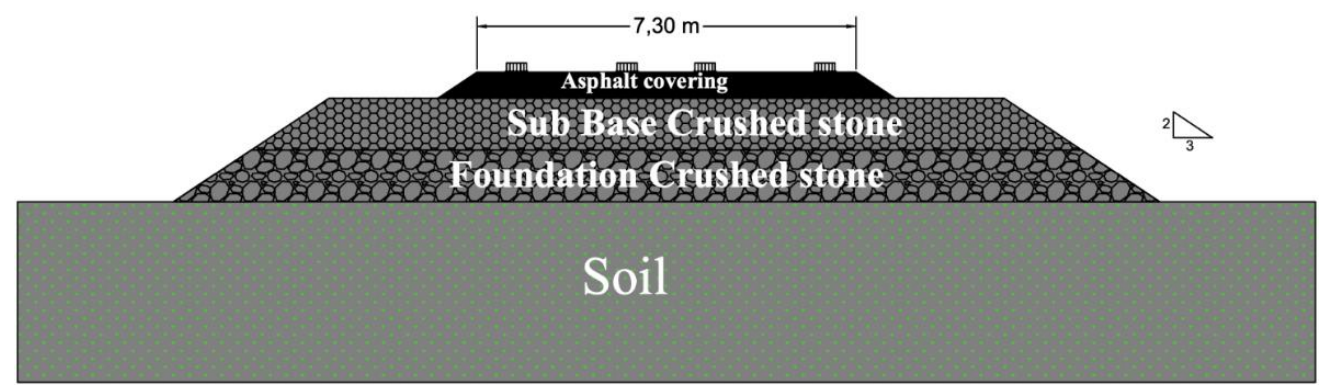

Figure 3. Width of the road, and loading areas 


\section{Soil Properties Used in Plaxis}

Mohr-coulomb model is accepted as a first order approximation of real soil behavior. This elastic- perfect plastic model requires five basic input parameters: Young's modulus (E), Poisson ratio $(v)$, cohesion (c), friction angle $(\varphi)$ and dilatation angle $(\psi)$. In table1, all parameters (including ground, sub-base, foundation, and asphalt properties) used in modeling are given.

Table 2. soil, subbase, foundation and asphalt Parameter properties

\begin{tabular}{|c|c|c|c|c|c|c|c|}
\hline Parameter & Symbol & $\begin{array}{l}\text { Asphalt } \\
\text { coering }\end{array}$ & $\begin{array}{l}\text { Sub Base } \\
\text { Crushed } \\
\text { stone }\end{array}$ & $\begin{array}{l}\text { Foundation } \\
\text { Crushed } \\
\text { stone }\end{array}$ & Sand & Clay-1 & Clay-2 \\
\hline Material model & & LE & $\mathrm{MC}$ & $\mathrm{MC}$ & $\mathrm{MC}$ & $\mathrm{MC}$ & $\mathrm{MC}$ \\
\hline Behavior type & & No drain & Drained & Drained & Drained & No drain & No drain \\
\hline $\begin{array}{l}\text { Dry unit weight } \\
{\left[\mathrm{kN} / \mathrm{m}^{3}\right]}\end{array}$ & $\gamma_{\text {unsat }}$ & 23.5 & 20 & 22 & 18 & 19 & 20 \\
\hline $\begin{array}{l}\text { Wet unit volume } \\
\text { weight } \\
{\left[\mathrm{kN} / \mathrm{m}^{3}\right]}\end{array}$ & $\gamma_{\mathrm{sat}}$ & - & 22 & 24 & 21 & 20 & 22 \\
\hline $\begin{array}{l}\text { Permeability in } \\
\mathrm{X} \text { direction } \\
{[\mathrm{m} / \text { day }]}\end{array}$ & $\mathrm{k}_{\mathrm{x}}$ & - & 1.000 & 1.000 & $5 \times 10^{-3}$ & 0 & 0 \\
\hline $\begin{array}{l}\text { Permeability in } \\
\text { Y direction } \\
\text { [m/day }]\end{array}$ & $\mathrm{k}_{\mathrm{y}}$ & - & 1.000 & 1.000 & $5 \times 10^{-3}$ & 0 & 0 \\
\hline $\begin{array}{l}\text { Young's modulus } \\
{\left[\mathrm{kN} / \mathrm{m}^{2}\right]}\end{array}$ & $\mathrm{E}_{50}$ & $120 \times 10^{5}$ & $100 \times 10^{3}$ & $120 \times 10^{3}$ & 25000 & $1.4 \times 10^{4}$ & $7.5 \times 10^{4}$ \\
\hline Poisson ratio [-] & v & 0.3 & 0.35 & 0.35 & 0.35 & 0.2 & 0.2 \\
\hline $\begin{array}{l}\text { Cohesion } \\
{\left[\mathrm{kN} / \mathrm{m}^{2}\right]}\end{array}$ & $\mathrm{C}$ & - & 30 & 20 & 0.025 & 10 & 20 \\
\hline $\begin{array}{l}\text { Angle of internal } \\
\text { friction }\left[{ }^{\circ}\right]\end{array}$ & $\varphi$ & - & 43 & 44 & 40 & 25 & 25 \\
\hline $\begin{array}{l}\text { Angle of } \\
\text { Dilatation }\left[{ }^{\circ}\right]\end{array}$ & $\Psi$ & - & 13 & 14 & 10 & 0 & 0 \\
\hline Reference & - & [22] & [19] & [20] & [23] & [21] & [21] \\
\hline
\end{tabular}




\section{Discussion and conclusions}

In this study, the beneficial effects of using different layered geosynthetics are investigated. Modeling was analyzed with the PLAXIS program used in the study. The output results show the beneficial effects of the axial stiffness of geosynthetics in the base layer and the interface strength of materials with a different base layer thickness on settlement, as it is shown in the figures.

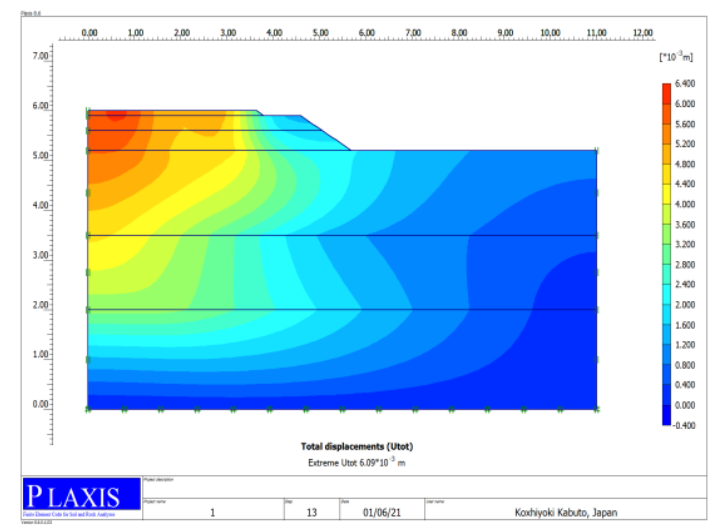

Model A1

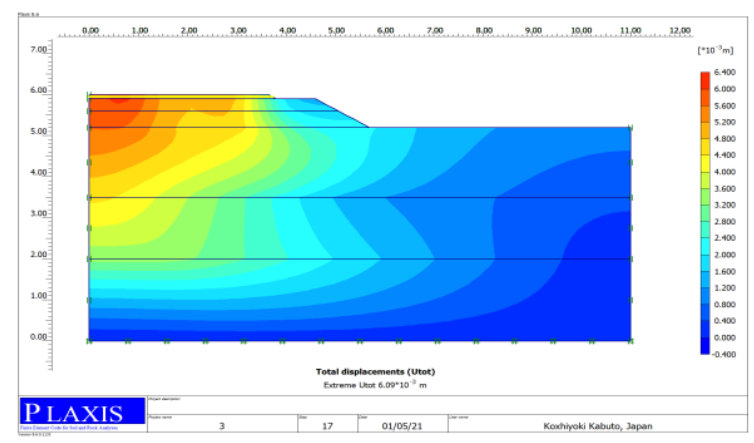

Model A2

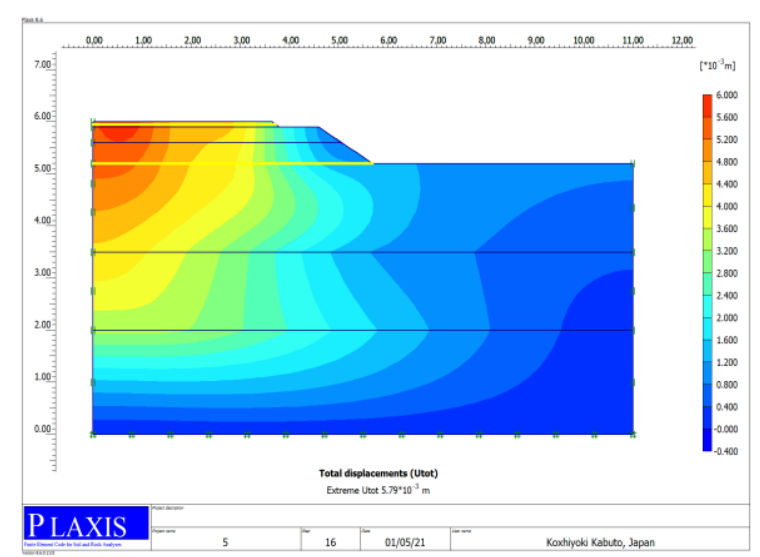

Model A3

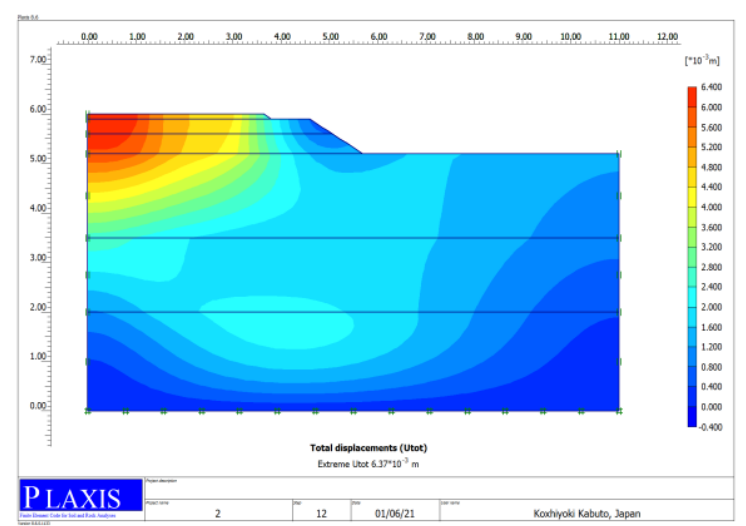

Model B1

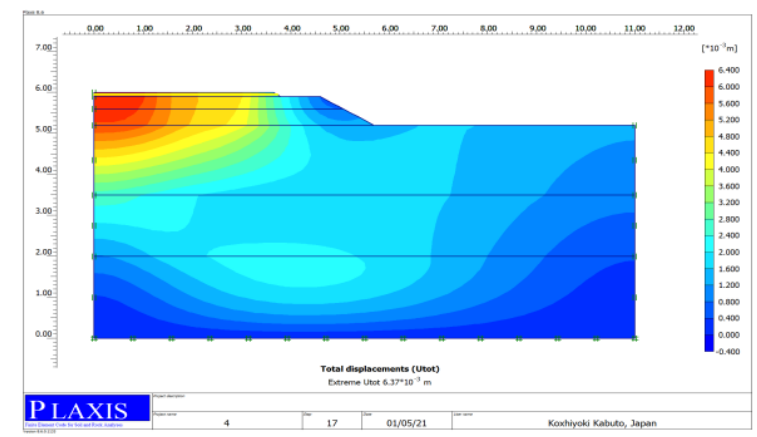

Model B2

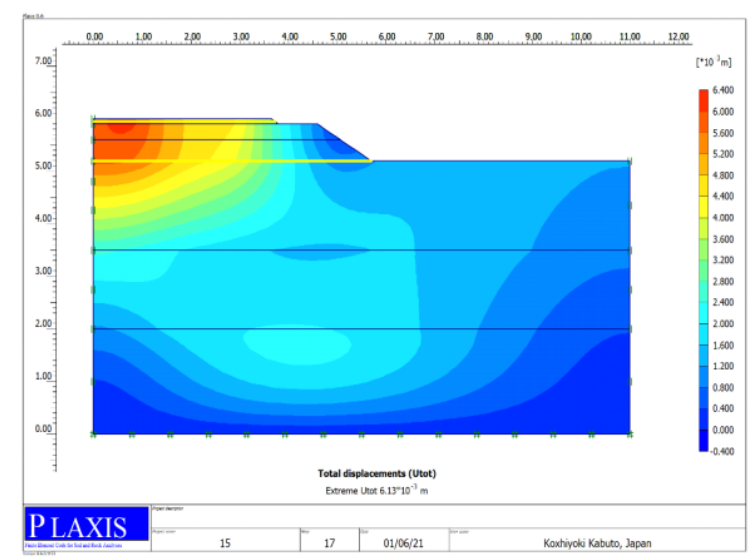

Model B3 


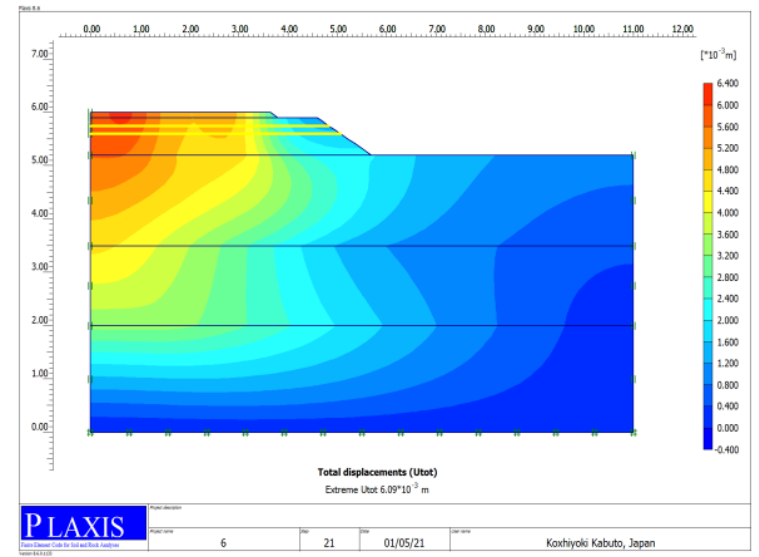

Model A4

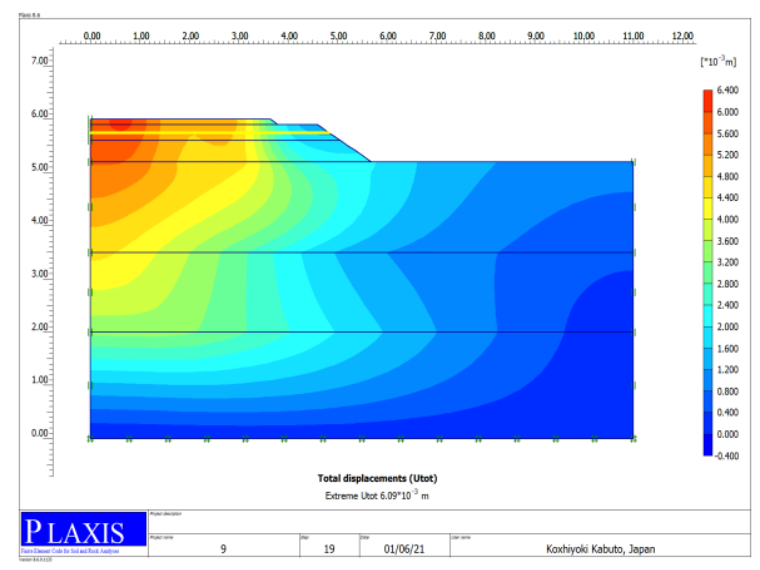

Model A5

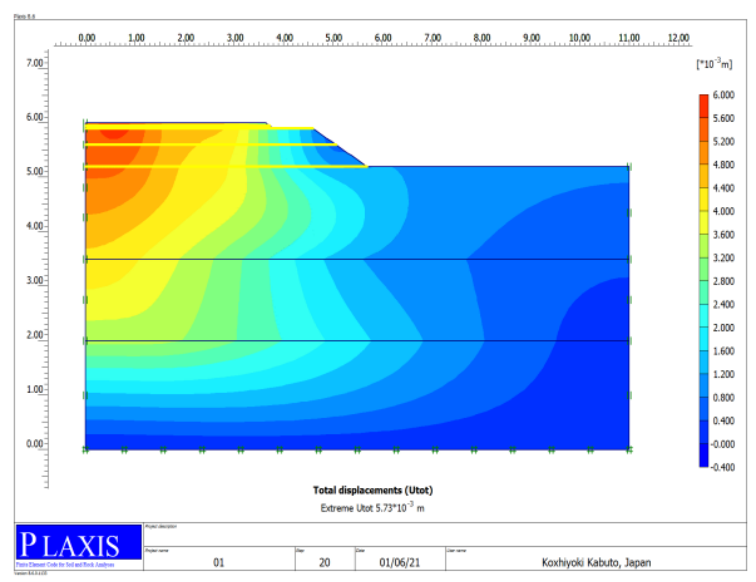

Model A6

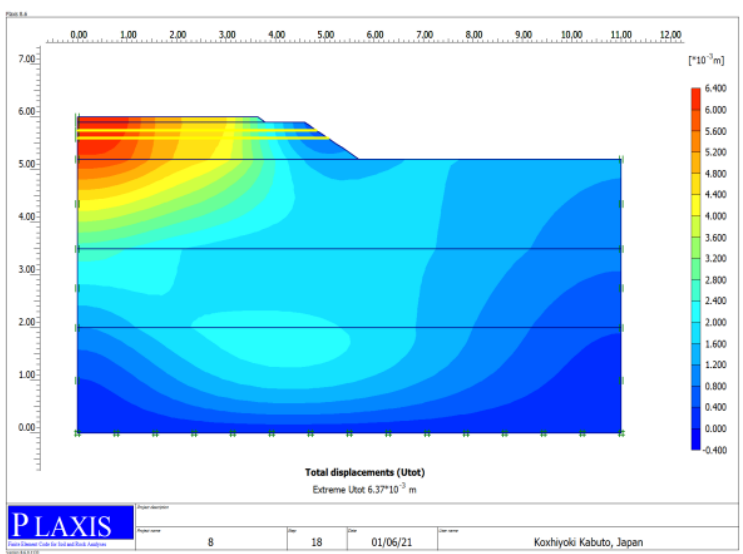

Model B4

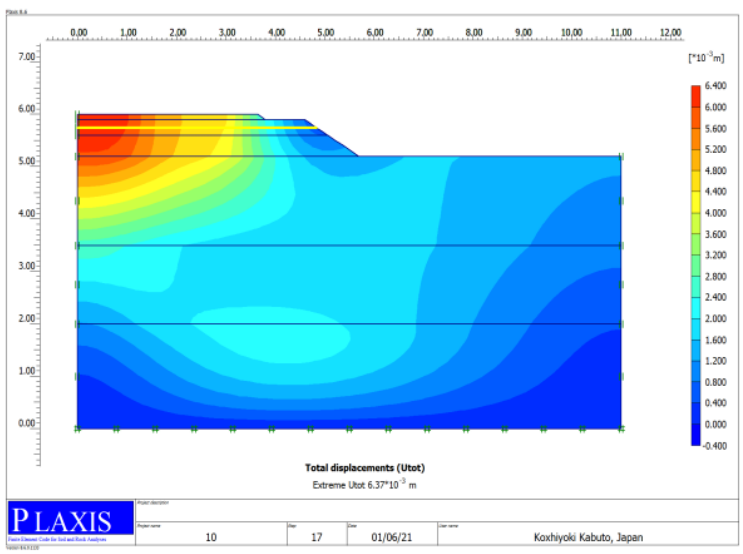

Model B5

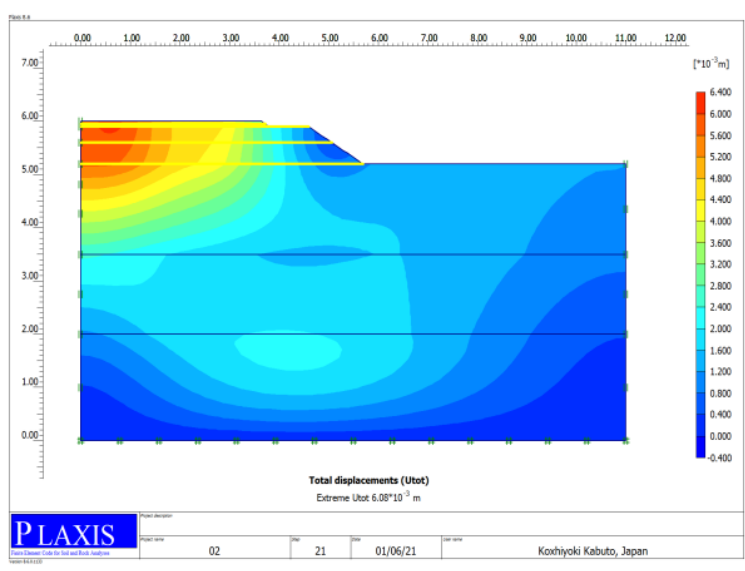

Model B6 


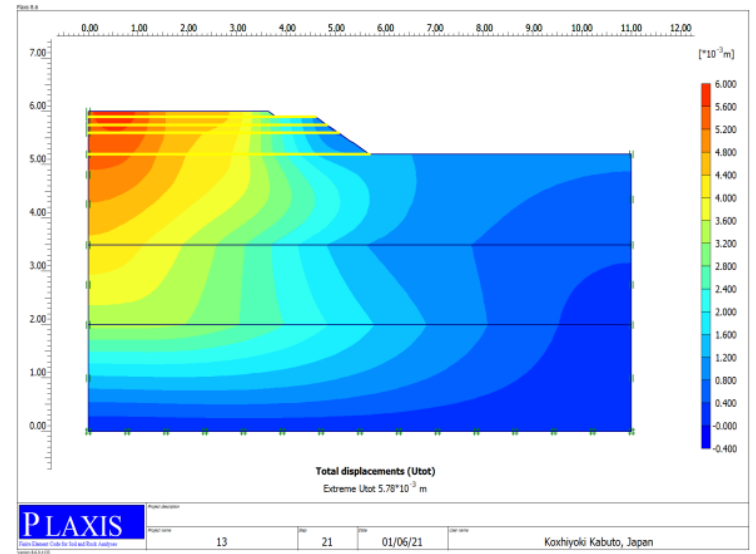

Model A7

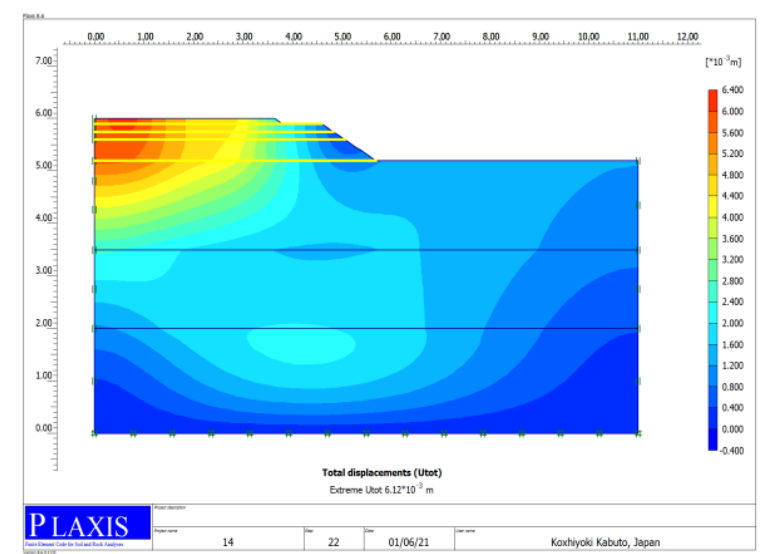

Model B7

Figure 4. Results of sitting in PLAXIS
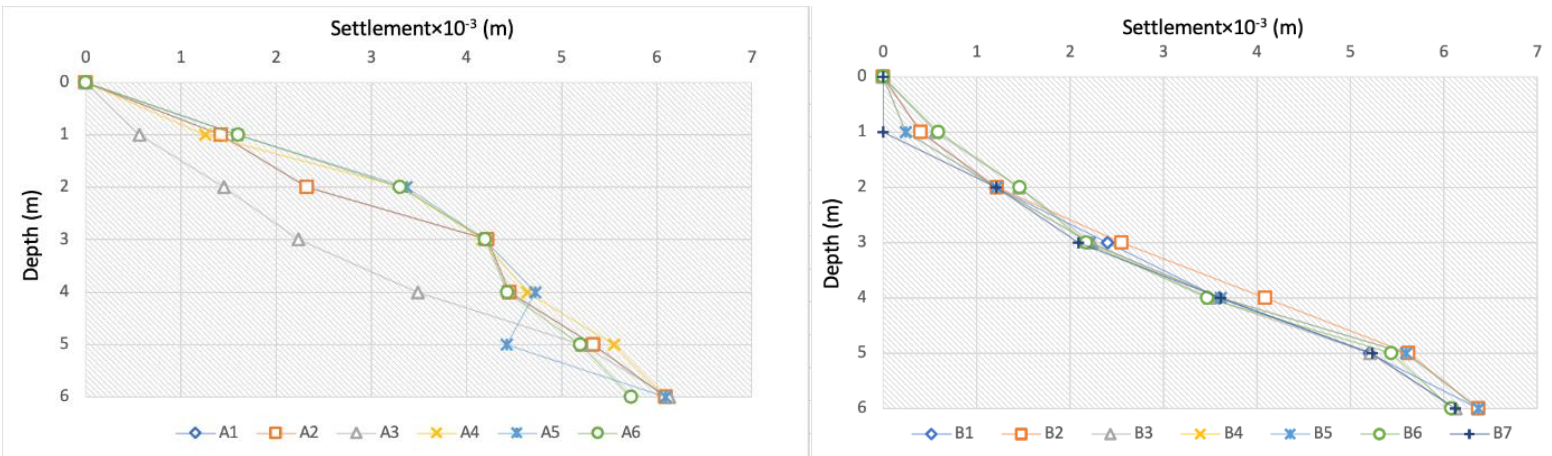

Figure 5. Settlement of different profiles with respect to depth

Results were determined for various parameters different for each model. These models are modeled without geogrid, using one or more layer geogrid, one or more layer geotextiles and these two products together in different layers. The two tires applied in these models transfer the a load of each tire to $246.2 \mathrm{kN} / \mathrm{m}^{2}$ of force. The model (A1) and model (B1) are shown in Figure 4 (A1, B1), which shows the total settlement results obtained without using geosynthetic materials. The settlement amount for model A1 is $6.09 \times 10^{-3} \mathrm{~m}$ and for model 2 the total displacement is $6.37 \times 10^{-3} \mathrm{~m}$. By comparison of these two models, it can be revealed that the order of sand clay liners have insignificant effect on the settlement of the embankment. Model (A2) and model (B2) are formed applying a single layer geogrid depicted in Figure 4. This means that two tires applied in the same models transfer the load of each tire $246.2 \mathrm{kN} / \mathrm{m}^{2}$. In Figure 4, the seating amount for model A2 is $6.09 \times 10^{-3} \mathrm{~m}$ and for model $\mathrm{B} 2$ the total seating is $6.37 \times 10^{-3} \mathrm{~m}$. Comparison of A1.B1 with A2 and B2 shows that in case of using a single layer of geogrid, the settlement does not change. In model (A3) and (B3) models, the amount of double layer geogrid settlement is formed as in Figure 4. In this way, the settlement amount appears to be a descent. In Figure 4, the settlement amount is calculated as $5.79 \times 10^{-3}$ $\mathrm{m}$ for model A3 and $6.13 \times 10^{-3} \mathrm{~m}$ for model B3. It can be concluded that if the two upper layers are clay, double layer is more effective than the sand as the upper layer. Model (A4) and (B4), double layer geotextile settlement amount was formed as in Figure 4. The amount of seating is calculated as $6.09 \times 10^{-3} \mathrm{~m}$ for model A4 and $6.37 \times 10^{-3} \mathrm{~m}$ for model B4 which does not have any effect with regard to the original case (A1 and B1). In (A5) and (B5) models, the total displacement for single layer geotextile is formed as in Figure 4. The settlement amount for model A5 was calculated to be $6.09 \times 10^{-3} \mathrm{~m}$ and model B5 to $6.37 \times 10^{-3} \mathrm{~m}$. In (A6) and (B6) models, the amount of settlement in the four-layer geogrid situation was formed as in Figure 2. The settlement amount for Model A6 is $5.73 \times 10^{-3} \mathrm{~m}$ and for model (B6) the total displacement is calculated as $6.08 \times 10^{-}$ ${ }^{3} \mathrm{~m}$. It is clear that increase in the number of geogrids has a effective impact in reduction of settlement though the rate of reduction decreases in application $f$ four geogrid layers. For models (A7) and (B7), the total displacement for two-layer geogrid and two-layer geotextile is $5.78 \times 10^{-3} \mathrm{~m}$ and for model (B7) the total displacement is $6.12 \times 10^{-3} \mathrm{~m}$.

Figure 5 (a) and (b) compares and summarizes the settlement rate at different layers of the soil at point $\mathrm{x}=0$ using geogrids and geotextiles.

\section{Modeling results}

Considering the applied analysis, finite element software PLAXIS- is capable of modeling the infrastructure of the paths appropriately. Analysis were performed using plane strain model. In plane strain, the strains out of plane (zdirection) are assumed as zero, therefore the depth of the model is set as zero. In these models, geosynthetics (geogrid and geotextile) are applied in different depths, different layers and different geosynthetic numbers according to the placement. Geosynthetic materials have been given a 
suitable solution to strengthen the sub-base and foundation in clay and sandy soils. The results obtained when using geosynthetic material in the foundation and subbases of the roads are presented as follows:

At the moment of the load transferred by the two tires of the vehicle, the first layer of clay soil was found to have less settlment than the first layer of sandy layer.

After application of geosynthetics in different layers of the road, the safety count decreased significantly,-Msf decreased. There is no effect on the use of single layer geotextiles and geogrids in models.

In the use of two-layer geogrid in models, the total displacement shows a decrease of $4.926 \%$ compared to the use of no geosynthetics. Application of geosynthetics seems to have no effect on the settlement reduction in all the cases.

Application of four-layer geogrid decreases the settlement, though the rate of reduction is not as severe as the case of 3 geogrids decrease. It can be concluded that the formation and order of layers with different soil types ( clay and sand) does not have any significant effect on the settlement rate.

\section{Ethics committee approval and conflict of interest statement}

There is no need to obtain permission from the ethics committee for the article prepared

There is no conflict of interest with any person / institution in the article prepared

\section{Authors' Contributions}

Mohammad Salem NOORI : Analysis, and interpretation of data, drafting of manuscript

Kaveh DEHGHANIAN: Conceived the original idea, supervised the project, critical revision

\section{References}

[1] Kazemian S., Huat B.K. (2010). Assessment of Stabilization Methods for Soft Soils by Admixtures, International Conference on Science and Social Research (Cssr2010), December 5-7, 2010, Kuala Lumpur, Malaysia.

[2] Majedi P, Celik S, Akbulut S (2016). Finite Element Modelling of Road Embankments Designed As Reinforced Slope, 1st National Young Geotechnic Engineers Symposium, Erzurum, Turkey.

[3] Paravita Sri Wulandaria, Daniel Tjandraa, Analysis of Geotextile Reinforced Road Embankment Using Plaxis 2D, the 5th International Conference of Euro Asia Civil Engineering Forum (Eacef-5).

[4] Andaç Bayram, Reinforcement of Airport Runway Fillings Using Geosynthetic Materials, June 2006, Master of Sciences Thesis, ITU, Turkey.

[5] S.K.Ahirwara , J.N. Mandala, Finite Element Analysis of Flexible Pavement With Geogrids, Transportation
Geotechnics and Geoecology, Tgg 2017, 17-19 May 2017, Saint Petersburg, Russia.

[6] Salahudeen, A. B. and Sadeeq, J. A, Numerical Modelling Of Soil Reinforcement Using Geogrids, February 23- 25, 2016, Fourth International Conference on Engineering LAUTECH Ahmadu Bello University, Zaria, Nigeria.

[7] Edinçliler, A. Murat Çalikoğlu, Improving the Seismic Performance of Low-Rise Structures Using Geosynthetics: Experimental Study, Seventh National Geosynthetics Conference 11-12 May 2017, Boğaziçi university, Istanbul.

[8] Şahin Çağlar Tuna, Eyyüb Karakan, Selim Altun, Investigation of Mechanical Behaviors of Geotextile Reinforced Sand Soils, İMo Teknik Dergi, 2015 7015-7022, Yazı 430, Teknik Not.

[9] Başak Çetin Karagül, Alignment of Road Fills Using Geogrid, January 2007, Master of Science thesis Istanbul Technical University.

[10] Gizem Çakar, Laboratory Investigation of Behavior of Geotextile Reinforced Clays, Balikesir, 2016 Master of Science thesis, Balikesir Üniversitesi.

[11] Mustafa Kocaer, Haziran 2011, Geosentetiklerin Karayolu Yapilarında Kullanimi: Türkiye Örnekleri, Master of Science thesis, Istanbul Technical University.

[12] Heerten, Georg, and J. Klompmaker. Improving the bearing capacity of soils with geosynthetics." 8th International Geotechnical Conference, Bratislava, Slovakia. 2007.

[13] Yedinci Ulusal Geosentetikler Konferansı 11-12 Mayıs 2017, BoğaziçiÜniversitesi, İstanbul.

[14] Francesca La Torre, Unifi, Italia (Avrupa Yol Yöneticileri Konferansı Yol Güvenliği Teknik Ekibinde (Cedr Tgrs) Anas Şirketini Temsilen), Haziran, 2018.

[15] Mustafa Alptekin Yolda, Karayollarinda Yol Sinıflandırması ve Tip Enkesitlerin İncelenmesi: Eminönü-Fatih Örneği, Yüksek Lisans Tezi, Eylül 2008, İstanbul Teknik Üniversitesi.

[16] Georg Heerten Improvement of Soil Properties, Bratislava on June 4 - 5, 2007.

[17] Plaxis Version 8 Tutorial Manual

[18] Https://www.Makinsantrailer.Com.Tr/Kuvet-TipiDamper

[19] Hamdy Faheem Mohamed Hassan, 30 December 2014, 2d Plaxis Finite Element Modeling Of AsphaltConcrete Pavement Reinforced With Geogrid, Article, Faculty of Eng., Minia University, Civil Engineering Department, Egypt

[20] Mostafa Deep Hashem, Ahmed Mousa Abu-Baker, December 2013, Numerical Modeling Of Flexible Pavement Constructed on Expansive Soils, Civil Engineering Department Faculty of Engineering, AlMinia University, Egypt. 
[21] A. Arda Bahadır, M. İnanç Onur, Derin Kazı Destek Sistemi Tasarımında Zemin Modeli Seçimi: Bir Vaka Analizi 7. GeoTeknik Sempozyumu 22-23-24 Kasım 2017, İstanbul.

[22] Waqed H. Almohammed, Mohammed Y. Fattah, Sajjad E. Rasheed, 2018, Numerical Analysis Of The Effect Of Geocell Reinforcement Above Buried Pipes on Surface Settlement And Vertical Pressure, World Academy Of Science, Engineering and Technology International Journal of Geotechnical and Geological Engineering.
[23] Bahatin GüNdüZ, December 2008. Analysis Of Settlements Of Test Embankments During 50 Years- A Comparison Between Field Measurements and Numerical Analysis, Master's Dissertation. Lunu University.

[24] Jorge G. Zornberg, Functions and applications of geosynthetics in roadways, Transportation Geotechnics and Geoecology, TGG 2017, 17-19 May 2017, Saint Petersburg, Russia. 